Beltrame María Ornela (Orcid ID: 0000-0002-7665-8576)

Serna Alejandro (Orcid ID: 0000-0001-6092-9848)

\title{
ZOONOTIC PARASITES IN FELINE COPROLITES FROM A HOLOCENIC MORTUARY CONTEXT FROM EASTERN PATAGONIA (ARGENTINA)
}

María Ornela Beltrame ${ }^{1,2}$, Alejandro Serna ${ }^{2,3}$, Victoria Cañal ${ }^{1}$, Luciano Prates ${ }^{2,3}$

${ }^{1}$ Laboratorio de Paleoparasitología. Instituto de Investigaciones en Producción, Sanidad y Ambiente (IIPROSAM), Universidad Nacional de Mar del Plata, Buenos Aires, Argentina.

${ }^{2}$ Consejo Nacional de Investigaciones Científicas y Técnicas (CONICET), Buenos Aires, Argentina.

${ }^{3}$ División Arqueología, Museo de La Plata. Universidad Nacional de La Plata, Buenos Aires, Argentina.

Corresponding author: María Ornela Beltrame. Laboratorio de Paleoparasitología, Departamento de Biología, Facultad de Ciencias Exactas y Naturales, Universidad Nacional de Mar del Plata, Funes 3250, 7600 Mar del Plata, Buenos Aires, Argentina. Tel 0054223 4753150, e-mail: ornelabeltrame@conicet.gov.ar.

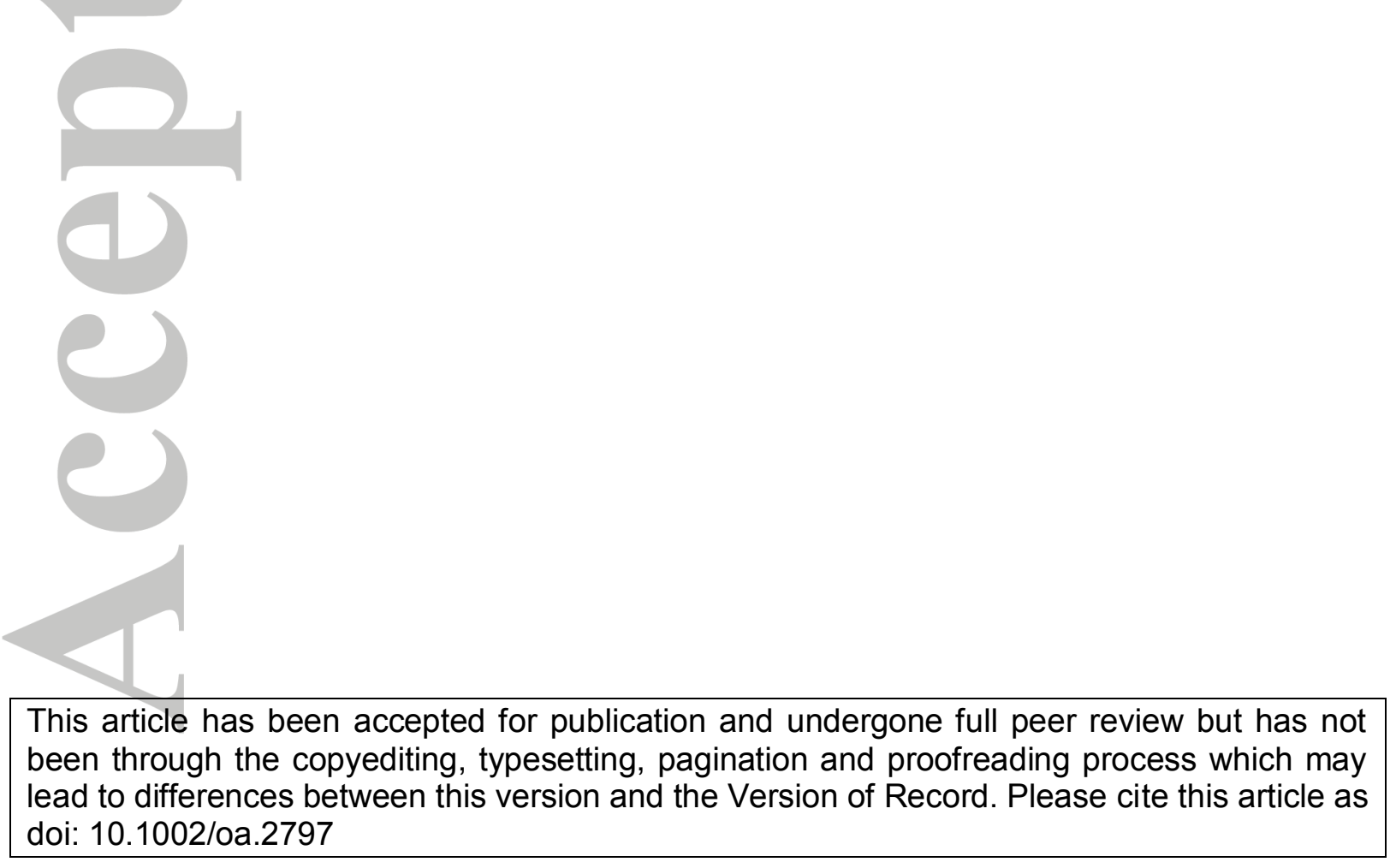

This article is protected by copyright. All rights reserved. 


\section{(c)}

ABSTRACT

Nowadays, wildlife is one of the most important sources of zoonoses, and it is a major concern for the public health. Nevertheless, little is known about the role of wildlife as a reservoir and source of infectious diseases in the past. South America presents a wide diversity of wildlife. In the south of the continent, Argentina shelters a large diversity of neotropical carnivores. Although the paleoparasitological studies on carnivores have been increasing in southern Argentina, most of the efforts have been focused in a handful of sites located in western Patagonia. In this paper, two coprolites of felid found in Cueva Galpón, an initial late Holocene mortuary site from northeast Patagonia (Argentina), were studied for paleoparasitological purposes. Samples were processed by rehydration, homogenization, filtered and processed by spontaneous sedimentation. The samples were assigned to Puma concolor (puma) or Panthera onca (jaguar). Microscopic observations revealed that both coprolites were positive for parasite remains. High parasite richness was observed. Six nematodes, one cestode and one coccidian morphotypes were reported. This is the first time that Gnathostoma sp. and Spirocerca sp. were recovered from holocenic times from Patagonia. This finding implies that some diseases such as taeniasis, spirocercosis, gnathostomosis, ascariasis and coccidiosis could be present in holocenic wildlife from Patagonia prior to the Spanish colonization and domestic animal introduction. The overall results suggest that felids could have played a role as reservoirs and source of some parasitic species, some of which are zoonotic. Therefore, this animal could have entailed a risk agent for human health in the site.

\section{KEYWORDS: PALEOPARASITOLOGY - ZOONOSES - HOLOCENE - CARNIVORES}




\section{INTRODUCTION}

Paleoparasitology is the study of parasites from ancient times, and some of its main interests are the origin and evolution of infectious diseases and parasites-hosts-environment relationships (Araújo et al., 2003; Reinhard et al., 2013). On this basis, paleoparasitology is able to provide knowledge of the major conditions of health and illness related to parasites in the past (Bouchet et al., 2003; Reinhard, 1992). Zoonoses are defined as infectious diseases that are naturally transmitted between vertebrate animal species and humans. The $60 \%$ of human emerging infectious diseases can also be catalogued as zoonotic (Jones et al., 2008). Nowadays, wildlife is one of the most important sources of zoonoses, and it is a major concern for the public health (Woods et al., 2019). Nevertheless, little is known about the role of the wildlife as reservoir and source of infectious diseases in the past (Sianto et al., 2009).

South America presents a wide diversity of wildlife. In the south of the continent, Argentina shelters a large diversity of neotropical carnivores (Bárquez et al., 2006; Teta et al., 2018). Although the paleoparasitological studies on carnivores have been increasing in southern Argentina (e.g. Beltrame et al., 2010, 2018; Fugassa et al., 2009, 2018), most of the efforts have been focused in a handful of sites located in western Patagonia. In this paper, the results of the first paleoparasitological study of the wild felid coprolites found in "Cueva Galpón", a late Holocene mortuary context from northeast Patagonia, are presented. Based on the parasitic richness found, their implications in term of zoonotic risk are discussed.

\section{MATERIALS AND METHODS}

"Cueva Galpón" (CG) is a mortuary archaeological context dated to the initial late Holocene (ca. 3000 years BP), located in the northeast of Patagonia region, Argentina. The site is located inside a rock shelter of ca. $50 \mathrm{~m}$ wide at the entrance and $10 \mathrm{~m}$ high, located on the eastern edge of the Pailemán hills. This shelter is filled with a sandy-silty deposit (60-65 $\mathrm{cm})$, sealed by an overlying layer of sheep dung ( $\sim 0.40 \mathrm{~cm}$ thick). Taking into account the origin of the sediments, four main sources of detrital components were defined: aeolian, from rocks detached from the bedrock roof, biological (dung) and anthropogenic (bones, wood, grasses and seeds). Most of the archaeological record of CG consists of scattered human remains, funerary goods (e.g. textiles, ornaments, a leather bag) and rock art, with no evidences of residential occupation (Carden and Prates, 2015; Prates et al., 2016). 
Two coprolites (named coprolite A and coprolite B) from CG were examined for paleoparasitological purposes. Coprolites examined come from $9 \mathrm{~cm}$ inside the sheep dung layer, level 2, and were dated at ca. 2900 years ${ }^{14} \mathrm{C}$ BP (Fernández et al. 2016). That means coprolites are almost contemporary (just later) than the mortuary deposit. The analysis started with the external observation of feces (color, texture, inclusions and measures) according to Chame (2003) and Jouy-Avantin (2003). Samples of $0.5 \mathrm{~g}$ from the interior of coprolites were rehydrated in a $0.5 \%$ water solution of tris-sodium phosphate (TSP). The remaining sample was whole processed by rehydration in TSP in a glass tube for at least $72 \mathrm{hs,} \mathrm{followed} \mathrm{by}$ homogenization, filtered and processed by spontaneous sedimentation (Lutz, 1919). Samples were preserved in $70 \%$ ethanol. At least 40 slides of each sample were made with the aid of a drop of sediment mixed with one drop of glycerin and examined at $100 \mathrm{X}$ and $400 \mathrm{X}$ using a light microscope Zeizz ${ }^{\circledR}$ Primo Star. Egg dimensions and morphology were compared with data from the literature in order to identify the parasites at the lowest taxonomic level. The macroscopic remains were separated and dried at room temperature and were examined for diet analysis.

\section{RESULTS}

Coprolites showed a whitish coloration, smooth surface and a hard and compact consistency (Fig. 1). The measurements of coprolite A were $28.25 \mathrm{~mm}$ width by $47.93 \mathrm{~mm}$ long and those of coprolite B were $28.65 \mathrm{~mm}$ width by $39.77 \mathrm{~mm}$ long. After rehydration, the supernatant exhibited a clear and yellowish coloration and presented an intense smell. Abundant micromammal hairs and fractured bones were observed in both coprolites, indicative of carnivorous diet.

Microscopic observations revealed that both coprolites were positive for parasite remains. Five nematodes and one coccidian species in coprolite A, and three nematodes and one cestode species in coprolite B were found. A total of six nematodes, one cestode and one coccidian species in both coprolites were observed.

Two oblong, colorless and larvated eggs with a thin and smooth wall were found in coprolite A. Measurements were $137.5 \mu \mathrm{m}$ by $75 \mu \mathrm{m}$ and 145 by $62.5 \mu \mathrm{m}$, and were compatible to strongylid eggs (Strongylida, Trichostrongyloidea) (Fig. 2a). Their morphology and measurements were similar to some species of Nematodirus sp. 
Thirty-five elliptical and larvated nematode eggs, with thick walls and slightly corrugated surfaces were found in coprolites A and B. Their measurements were 37.5 to 47.5 $\mu \mathrm{m}(43.97 \pm 4.59)$ in length and 27.5 to $37.5 \mu \mathrm{m}(31.47 \pm 3.96)$ in width $(\mathrm{n}=20)$. This nematode was assigned to the superfamily Spiruroidea (Order Spirurida) (Fig. 2b).

Nematode eggs with thick walls and slightly corrugated surfaces were observed in both coprolites. Their measurements were 65.0 to $72.5 \mu \mathrm{m}(68.26 \pm 3.22)$ in length and 32.5 to $37.5 \mu \mathrm{m}(35.75 \pm 2.89)$ in width $(\mathrm{n}=4)$. Eggs were attributed to an ascaridid species (Ascaridida, Ascarididae), tentatively Lagochilascaris sp. (Fig. 2c).

Two nematode eggs with single thick wall and with a rounded pole and the other sharp, without operculum and larvated were found in coprolite A. The measurements $(n=1)$ were $137.5 \mu \mathrm{m}$ by $62.5 \mu \mathrm{m}$. and were assigned to Heteroxynema (Cavioxyura) viscaciae (Oxyuroidea, Heteroxynematidae) (Fig. 2d),

Two nematode eggs, elongated, with parallel sides, thick and smooth shell and larvated were found in coprolite A. The measurements of both eggs were $37.5 \mu \mathrm{m}$ long by $17.5 \mu \mathrm{m}$ wide (Fig. 2e). The eggs were attributed to Spirocerca sp. (Spirurida, Spirocercidae)

Taeniid eggs were found in coprolite B (Cyclophyllidea, Taeniidae). Eggs were spherical with yellow-brown and striated shell and with three pairs of hooks inside. The measurements were 32.7 to $37.5 \mu \mathrm{m}(33.62 \pm 3.11)$ in width and 37.5 to $42.5 \mu \mathrm{m}(39.89 \pm$ 3.37) in long (n=12) (Fig. 2f). Eggs were identified as Taenia sp. or Echinococcus sp.

Two eggs of nematodes, oval, unembryonated, with a thin and pitted shell and one polar bulge were also found in coprolite B (Fig. 2g). Measurements were 60 by $42.5 \mu \mathrm{m}$ and 52.5 by $37.5 \mu \mathrm{m}$. Eggs were attributed to Gnathostoma sp. (Spirurida: Gnathostomatidae).

One oocyst (Coccidia, Apicomplexa) was found in coprolite A (Fig. 2h). Their measurements were $25 \mu \mathrm{m}$ by $26 \mu \mathrm{m}$. 


\section{DISCUSSION}

\section{Coprolites determination}

Both coprolites were identified as belonging to a large felid (Carnivora, Felidae) based on shape, coloration, size and content (Chame, 2003; Jouy-Avantin, 2003). Nowadays, the only species of large felid inhabiting the area is Puma concolor (puma, mountain lion or cougar). The distribution range extends from northern British Columbia (Canada) to southern Patagonia (Chile and Argentina). Nevertheless, the presence of another large felid, Panthera onca (yaguareté or jaguar), before $20^{\text {th }}$-century has been also proposed on the basis of ethnohistorical, archaeological and paleontological data (Cabrera and Yepes, 1960; Rusconi, 1967; De Angelis, 1972; Cardich, 1979; Redford and Eisenberg, 1992; Diaz, 2010). Some rock art motifs at the site suggest that humans could have represented a $P$. onca. In this regard, Carden and Prates (2015) described felid footprints and black empty circles with red dots inside, which closely resemble to the coat of that great felid. Similar motifs associated with a yaguareté-shaped figure have been recorded at El Ceibo site in southern Patagonia (Cardich, 1979). Although this archaeological information becomes relevant for the evaluation of human-felid interactions at the site, the morphological and parasitological results are not conclusive for determining at species level.

\section{Paleoparasitological findings and zoonotic risk}

Several parasites taxa were found at the site: six nematode species, one coccidian and one cestode. Our results show a high richness of gastrointestinal parasites. The variability in the parasitic contents of both samples, could suggest that they corresponded to separate events, despite exhibiting a common zoological origin.

Nematodirus spp., one of the most common parasitic nematodes in ruminants worldwide, occurs in the small intestine. Nematodes of this genus are important disease-causing parasites, on occasions causing severe pathology and even deaths. A characteristic of this genus is that development to the infective third larval stage (L3) occurs within the egg, allowing them to persist on pasture for long periods (Anderson, 2000). Their presence in carnivores is accidental by ingestion of an herbivore prey. Nematodirus spp. eggs were previously reported from Holocene samples from Patagonia, such as coprolites assigned to camelids (Taglioretti et al., 2015, 2017) and coprolites assigned to felines (Fugassa et al., 
2009). Although this genus is not considered zoonotic, their presence in the environment indicates the potential presence of the disease in the wildlife in the past.

Ascaridids are mainly parasites of terrestrial hosts and their transmission commonly involves terrestrial invertebrates and small mammal paratenic or intermediate hosts. However, the eggs of some species are directly infective to the definitive host (Anderson, 2000). Previous studies on carnivores from southern South America stated that ascaririd species found were Toxocara cati, Toxascaris leonina and Lagochilascaris major (e.g. Beldoménico et al., 2005; González-Acuña et al., 2010; Martínez et al., 2010; Moleón et al., 2015; Scioscia et al., 2018; Vega et al., 2018). Species belonging to these three genera are zoonotic. The morphology of the ascaridid eggs found in this study was similar to those of Lagochilascaris. Lagochilascaris minor was found from P. concolor from Mexico (FalcónOrdaz et al., 2016). The life cycle of Lagochilascaris is heteroxenous, involving natural definitive hosts (wild carnivores), accidental hosts (domestic carnivores and humans) and intermediate hosts. Human lagochilascariasis is a zoonotic disease with neotropical distribution. Lagochilascariosis is an emerging parasitic disease in the Americas caused by the nematode Lagochilascaris spp. and is distributed from Mexico to Argentina and the Caribbean Islands. Five species have been recognized in this genus. Lagochilascaris minor and L. major are the two most commonly reported species and both are biologically similar and produce similar injuries. L. minor is the etiological agent of human lagochilascariasis in South America and Mexico, where it is associated generally with purulent abscesses in the region of the ear, neck, jaw, orbit, mastoid process and retropharyngeal tissues. Humans can serve as a definitive host but the route of infection is unknown. The studies suggests that humans might acquire this strange nematode from eating uncooked or poorly cooked flesh of some rodents serving as intermediate hosts. There is, however, no explanation for the large number of worms at various stages of development reported in human infections (Anderson, 2000; Campos et al., 2017).

Heteroxynematidae includes nematodes that evolved in sciuromorph, caviomorph and miomorph mammals. Heteroxynema viscaciae is a parasite found in the caecum and large intestine from Lagidium viscacia (mountain viscacia) (Hugot and Sutton, 1989) and wild viscachas Lagostomus maximus (Foster et al., 2002; Ferreira et al., 2007) from South America. Heteroxynema viscaciae was also found in ancient coprolites assigned to $L$. viscacia from Patagonia (Beltrame et al., 2014). Their presence in felines is accidental by ingestion of viscachas. Lagidium viscacia hair remains were found in the human mortuary 
context of CG (Prates et al., 2016), indicating its presence and exploitation in the site. However, this species does not present any zoonotic risk.

Spirocerca sp. is found worldwide especially in tropical and subtropical regions. This nematode has been found in many species, but affects mostly carnivores, especially Canidae (Mazaki-Tovi et al., 2002; Rojas et al., 2018). The life cycle of Spirocerca lupi is the most studied and involves intermediate and paratenic hosts. The adult worms are found coiled within nodules in the oesophageal wall. Spirocerca lupi eggs containing larvae (L1) are passed from the oesophagus through the gastrointestinal tract and into the feces or may be shed in the vomitus. Eggs are ingested by the intermediate host (coprophagous beetles) and the larvae encyst within the tissues and develop to infectivity (L3) within two months. The beetle is ingested by the final host or a paratenic host (which include birds, lizards and rodents). Spirocercosis is a disease caused by this nematode which has a variety of clinical presentations. Death is typically a result of malignant neoplasms or aortic aneurysms (Mazaki-Tovi et al., 2002; Yogeshpriya, 2016; Van der Merwe et al., 2008; Rinas et al., 2009). This is the first report of Spirocerca sp. from ancient times from South America. Human spirocercosis was not reported at the moment. Therefore, although it is not a zoonotic species, its presence indicates the potential presence of the disease in wildlife in ancient times.

Gnathostomosis, a neglected food-borne zoonotic parasitic disease mostly in tropical and subtropical regions, is spread all over the world. Members of the genus Gnathostoma generally occur in tumors in the stomach wall of carnivorous mammals but two species occur in the kidneys and the oesophagus. Dogs, felines and wild mammals serve as the definitive hosts in the life cycle of the nematode, which has two intermediate hosts (Anderson, 2000). The first intermediate hosts are crustaceans and copepods. The second intermediate hosts are fresh-water fishes, frog, turtles and snakes harboring the infective third-stage larvae. Gnathostomosis can cause an extremely wide range of symptoms, such as cutaneous lesions and visceral disease, which damage pulmonary, gastrointestinal, genitourinary, ocular, auricular and central nervous system Infection occurs by ingesting raw or insufficiently cooked fresh fish meat contaminated with the third-stage larvae. There are numerous cases reported in humans (Moore et al., 2003; Herman and Chiodini, 2009; Katchanov et al., 2011; Bravo, 2018). This is the first time that Gnathostoma sp. is reported from ancient times. Therefore, the presence of this species in the past displays the potential presence of the gnathostomosis both in carnivores and humans from holocenic times from Patagonia. 
The family Taeniidae is of great importance in the medical and veterinary fields, particularly in the tropics and subtropics. All taeniid parasites have complex life cycles that include a carnivorous (or omnivorous) definitive host and a second mammalian intermediate host (herbivores, mainly artiodactyls, rodents, and lagomorphs) in which the larval or metacestode develops. The cycle is completed when eggs voided with the feces of infected final hosts contaminate vegetation that subsequently is eaten by the intermediate hosts. Eggs of Taenia and Echinococcus spp. are impossible to identify because they are all quite similar (Samuel et al., 2001). Humans are an aberrant host that does not play a role in the natural cycle of the parasite. Wildlife is essential for maintaining the life cycle of some taeniids in nature. Cysticercosis/Taeniasis and echinococcosis are neglected and cosmopolitan zoonotic diseases of public health significance caused by Taenia spp. and Echinococcus spp., respectively. Nowadays, both diseases are an important public health problem in South America. Several socioeconomic and cultural factors influence the transmission (Acha and Szyfres, 2003). Living or having lived in rural areas where farming and animal husbandry are common is an important risk factor for these diseases; in some areas particularly where people frequently come in contact with domestic and wild animals as well as where wild animal hunting for food is a common practice (e.g., hunters and aboriginal people). Humans and wildlife who lived in this site may have been exposed to these mention diseases in ancient times.

One of the most remarkable features of $\mathrm{CG}$ is that the site was occasionally and almost exclusively visited by humans with symbolic (mortuary and artistic) purposes, with no evidence of human residential use (Carden and Prates, 2015; Prates et al., 2016). Since the cave offers appropriate conditions for both human occupation and archaeological visibility/preservation (see discussion in Straus, 1990; Prates et al., 2013), the lack of archaeological remains of residential use is indeed an unexpected attribute. Though different causes could be related to this feature, two suggestive hypotheses emerge from our results. On the one hand, as pointed above, CG could have been a zoonotic risk zone, due to the presence of zoonotic parasites. However, it does not seem to explain the human reticence to the residential use of the cave. Not only because it is unlikely that the hunter-gatherers could have recognized this potential zoonotic risks, but also because most of the residential archaeological sites of Patagonia come from similar sheltered environments (caves and overhangs). On the other hand, spatial competition between humans and great felids could have discouraged the latter from settle in the cave. 


\section{CONCLUSION}

The samples studied in the present work were assigned to a large felid, Puma concolor (puma) or Panthera onca (yaguareté). The paleoparasitological study shows high parasite richness and new parasite species for archaeological contexts were finding. Six nematode species, one cestode and one coccidian were reported. Gnathostoma sp. and Spirocerca sp. are the first records of these genera for Holocene contexts from Patagonia. On the other hand, diseases such as taeniasis, spirocercosis, gnathostomosis, ascariasis and coccidiosis could be present in wildlife from southern South America prior to the Spanish colonization and domestic animal introduction due to the presence of the parasite remains mentioned previously. Also, this means that felids could have played a role as reservoirs and sources of some parasitic species, some of which are zoonotic. Therefore, this animal could have entailed a risk agent for human health in the site.

\section{BIBLIOGRAPHY}

Acha P, Szyfres B. 2003. Zoonoses and communicable diseases common to man and animals. In: Parasitoses, vol III, 3rd edn. PAHO, Washington DC.

Anderson RC. 2000. Nematode parasites of vertebrates: Their development and transmission, 2nd ed. CABI Publishing, Oxford, U.K., 672 pp.

Araújo A, Jansen AM, Bouchet F, Reinhard K, Ferreira LF. 2003. Parasitism, the diversity of life, and paleoparasitology. Memórias do Instituto Oswaldo Cruz, 98: 5-11.

Bárquez R, Díaz MM, Ojeda, RA. 2006. Mamíferos de Argentina: sistemática y distribución. Sociedad Argentina para el estudio de los mamíferos, Tucumán.

Beldoménico PM, Kinsella JM, Uhart MM, Gutierrez GL, Pereira J, Ferreyra H, Marull CA. 2005. Helminths of Geoffroy's cat, Oncifelis geoffroyi (Carnivora, felidae) from the Monte desert, central Argentina. Acta Parasitologica 50: 263-266.

Beltrame MO, Fugassa MH, Sardella NH. 2010. First paleoparasitological results from Late Holocene in patagonian coprolites. Journal of Parasitology 96(3):648-651.

Beltrame MO, Vieira de Souza V, Araújo A, Sardella NH. 2014. Review of the rodent paleoparasitological knowledge from South America. Quaternary International 352: 68-74.

Beltrame MO, Bellusci A, Fernández FJ, Sardella NH. 2018. Carnivores as zoonotic parasite reservoirs in ancient times: the case of the Epullán Chica archaeological cave (Late Holocene, 
northwestern Patagonia, Argentina). Archaeological and Anthropological Sciences 10: 795804.

Bouchet F, Guidon N, Dittmar K, Harter S, Ferreira LF, Chaves SM, Reinhard K, Araújo A. 2003. Parasite remains in archaeological sites. Memórias do Instituto Oswaldo Cruz 98: 4752.

Bravo F. 2018. Gnathostomiasis: an emerging infectious disease relevant to all dermatologists. Anais Brasileiros de Dermatologia 93(2):172-80.

Cabrera A, Yepes J. 1960. Mamíferos Sudamericanos. Ediar, Buenos Aires.

Campos DMB, Barbosa AP, Oliveira JAd, Tavares GG, Cravo PVL, Ostermayer AL. 2017. Human lagochilascariasis - A rare helminthic disease. PLoS Neglected Tropical Diseases 11(6): e0005510.

Carden N, Prates L. 2015. Pinturas rupestres en un espacio funerario: el Caso del sitio Cueva Galpón (departamento de Valcheta, Río Negro). Magallania 43: 117-136.

Cardich A. 1979. A propósito de un motivo sobresaliente en las pinturas rupestres de "E1 Ceibo" (Provincia de Santa Cruz, Argentina). Relaciones de la Sociedad Argentina de Antropología 13:163-182.

Chame M. 2003. Terrestrial mammal feces: a morphometric summary and description. Memórias do Instituto Oswaldo Cruz 98:71-94.

De Angelis P. 1972. Discurso preliminar al diario de Viedma. Colección de Obras y Documentos. Plus Ultra, Buenos Aires. Pp. 797-818.

Diaz NI. 2010. New historical records of the jaguar (Panthera onca) in Patagonia. Revista Mexicana de Mastozoología (Nueva Época) 14: 23-35.

Falcón-Ordaz J, Iturbe-Morgado JC, Rojas-Martínez AE, García- Prieto L. 2016. Lagochilascaris minor (Nematoda: Ascarididae) from a wild cougar (Puma concolor) in Mexico. Journal of Wildlife Diseases 52(3):746-748.

Ferreira H, Uhart MM, Romano MC, Beldoménico PM, Samartino L, Paolicchi F, Lauricella M, Jorge MC, Schettino A, Guida N, Martín AM. 2007. Inmovilización química y evaluación de salud de vizcachas salvajes (Lagostomus maximus) en el Chaco árido argentino. Arquivos de Ciências Veterinárias e Zoologia da UNIPAR 10: 91-99.

Fernández FJ, Teta P, Mange E, Prates L, González Venanzi L, Pardiñas UFJ. 2016. Micromamíferos del sitio arqueológico Cueva Galpón (Río Negro, Argentina): Aspectos tafonómicos y reconstrucción paleoambiental para el Holoceno Tardío en Norpatagonia oriental. Arqueología 22 Dossier: 105-124.

Foster GW, Branch LC, Marchiote M, Kinsella JM, Villarreal D, Forrester DJ. 2002. Gastrointestinal helminths of the plains vizcacha (Lagostomus maximus) from Argentina, 
with observations on interspecific interactions between nematodes and cestodes, Comparative Parasitology 69: 26-32.

Fugassa MH, Beltrame MO, Bayer MS, Sardella NH. 2009. Zoonotic parasites associated with felines from the Patagonian Holocene. Memórias do Instituto Oswaldo Cruz 104:11771180 .

Fugassa MH, Petrigh RS. 2018. Apex predators, rockshelters, and zoonoses in the Patagonian Holocene. Journal of Parasitology 103:791-794.

González-Acuña D, Moreno L, Ardiles K, Flores M, Duclos M, Kinsella M. 2010. Endoparasites of the kodkod, Oncifelis guigna (Carnivora, Felidae) in Chile. Revista Chilena de Historia Natural 83:619-622.

Herman JS, Chiodini PL. 2009. Gnathostomiasis, another emerging imported disease. Clinical Microbiology Reviews 22:484-492.

Hugot JP, Sutton CA. 1989. Contribution à la connaissance de la faune parasitaire d' Argentine, XV. Etude morphologique de Heteroxynema (Cavioxyura) viscaciae n. Sp. (Nematoda, Heteroxynematidae) parasite de Lagidium viscacia boxi (Mammalia, Rodentia). Systematic Parasitolology 13:111-120.

Jones KE, Patel NG, Levy MA, Storeygard A, Balk D, Gittleman JL, Daszak P. 2008. Global trends in emerging infectious diseases. Nature 451, 990-993.

Jouy-Avantin, F. 2003. A Standardized method for the description and the study of coprolites. Journal of Archaeological Science 30:367-372.

Katchanov J, Sawanyawisuth K, Chotmongkoi V, Nawa Y. 2011. Neurognathostomiasis, a neglected parasitosis of the central nervous system. Emerging Infectious Diseases 17:11741180 .

Lutz A. 1919. Schistosoma mansoni e a schistosomatose segundo observaçoes feitas no Brasil. Memórias do Instituto Oswaldo Cruz 1:121-155.

Martínez FA, Binda, JL, Laffont G, Rodriguez Camon M. 2010. The most frequent parasitosis in wild feline. Veterinaria Argentina 27:1-6.

Mazaki-Tovi M, Baneth G, Aroch I, Harrus S, Kass PH, Ben-Ari T, Zur G, Aizenberg I, Bark H, Lavy E. 2002. Canine spirocercosis: clinical, diagnostic, pathologic, and epidemiologic characteristics. Veterinary Parasitology 107:235-250.

Moleón MS, Kinsella JM, Moreno PG, Del Valle Ferreyra H, Pereira J, Pía M, Beldoménico PMN. 2015. New hosts and localities for helminths of carnivores in Argentina. Zootaxa 4057: $106-114$

Moore DA, Mccroddan J, Dekumyoy P, Chiodini PL. 2003. Gnathostomiasis: an emerging imported disease. Emerging Infectious Diseases 9:647-650. 
Prates L, Politis G, Steele J. 2013. Radiocarbon chronology of the early human occupation of Argentina. Quaternary International 301:104-122.

Prates L, Ballejo F, Blasi A. 2016. Analysis of hair remains from a hunter-gatherer grave from Patagonia: Taxonomic identification and archaeological implications. Journal of Archaeological Science: Reports 8:142-146.

Redford KH, Eisenberg JF. 1992. Mammals of the Netropics: The Southern Cone, Vol. 2. The University of Chicago Press, Chicago and London.

Reinhard KJ. 1992. Parasitology as an interpretative tool in archaeology. American Antiquity 57:231-245.

Reinhard KJ, Ferreira LF, Bouchet F, Sianto L, Dutra JMF, Iñiguez A, Leles D, Le Bailly M, Fugassa M, Pucu E, Araujo A. 2013. Food, parasites, and epidemiological transitions: a broad perspective. International Journal of Paleopathology 3:150-157.

Rinas MA, Nesnek R, Kinsella JM, De Matteo KE. 2009. Fatal aortic aneurysm and rupture in a neotropical bush dog (Speothos venaticus) caused by Spirocerca lupi. Veterinary Parasitology 164:347-349.

Rojas A, Sanchis-Monsonís G, Alić A, Hodžić A, Otranto D, Yasur-Landau D, MartínezCarrasco C, Baneth G. 2018. Spirocerca vulpis sp. nov. (Spiruridae: Spirocercidae): description of a new nematode species of the red fox, Vulpes vulpes (Carnivora: Canidae). Parasitology 145:1917-1928.

Rusconi C. 1967. Animales extinguidos de Mendoza y de la Argentina. Author's edition, Mendoza, Argentina.

Samuel WM, Pybus MJ, Kocan AA. 2001. Parasitic diseases of wild mammals. 2nd Edition, Iowa State University Press, 559 pp.

Scioscia NP, Olmos L, Gorosábel A, Bernad L, Pedrana J, Denegri GM, 2018. Natural infection in Pampas fox (Lycalopex gymnocercus) by Lagochilascaris major Leiper, 1910 (Nematoda: Ascarididae) in Buenos Aires, Argentina. Parasitology Research 117(9):30233027.

Sianto L, Chame M, Silva CSP, Gonçalves MLC, Reinhard K, Fugassa M, Araújo A. 2009. Animal helminthes in human archaeological remains: a review of zoonoses in the past. Revista do Instituto de Medicina tropical do São Paulo 51(3):119-130.

Straus LG. 1990. Underground archaeology: perspectives on caves and rockshelters. Archaeological method and theory 2:255-304.

Taglioretti V, Fugassa MH, Sardella NH. 2015. Parasitic diversity found in coprolites of camelids during the Holocene. Parasitology Research 114(7):2459-64. 
Taglioretti V, Fugassa MH, Rindel D, Sardella NH. 2017. New parasitological findings for pre-Hispanic camelids. Parasitology 144(13):1763-1768.

Teta P, Abba AM, Cassini GH, Flores DA, Galliari CA, Lucero SO, Ramírez M. 2018. Lista revisada de los mamíferos de Argentina. Mastozoología Neotropical 25:163-198.

Yogeshpriya S. 2016. A complete overview on spirocercosis in dogs. International Journal of Food, Agriculture and Veterinary Sciences 6:16-20.

Van der Merwe LL, Kirberger RM, Clift S, Williams M, Keller N, Naidoo V. 2008. Spirocerca lupi infection in the dog: A review. The Veterinary Journal 176:294-309.

Vega RM, González Prous C, Krivokapich S, Gatti G, Brugni NL, Semenas L. 2018. Toxocariasis in Carnivora from Argentinean Patagonia: Species molecular identification, hosts, and geographical distribution. IJP: Parasites and Wildlife 7:106-110.

Woods R, Reiss A, Cox-Witton K, Grillo T, Peters A. 2019. The importance of wildlife disease monitoring as part of global surveillance for zoonotic diseases: the role of Australia. Tropical Medicine and Infectious Diseases 4, 29.

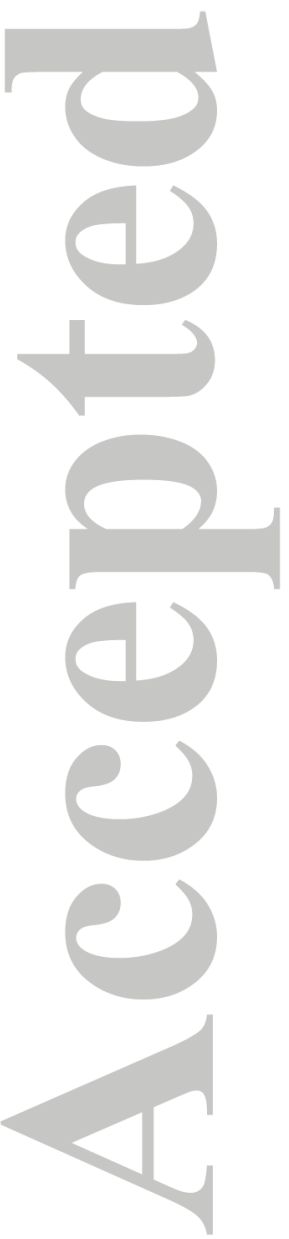




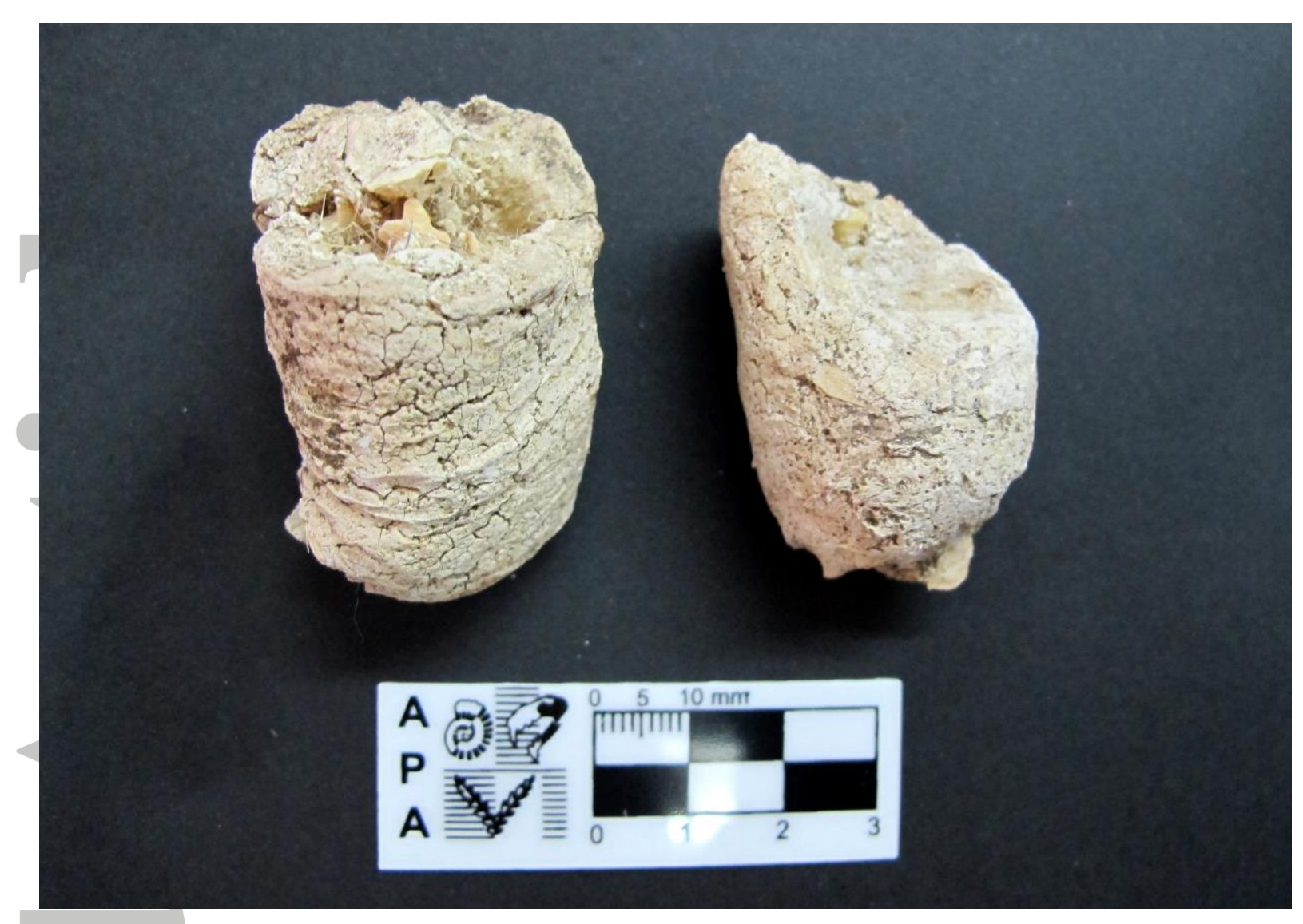

Figure 1: Studied samples from Cueva Galpón, Patagonia, Argentina.

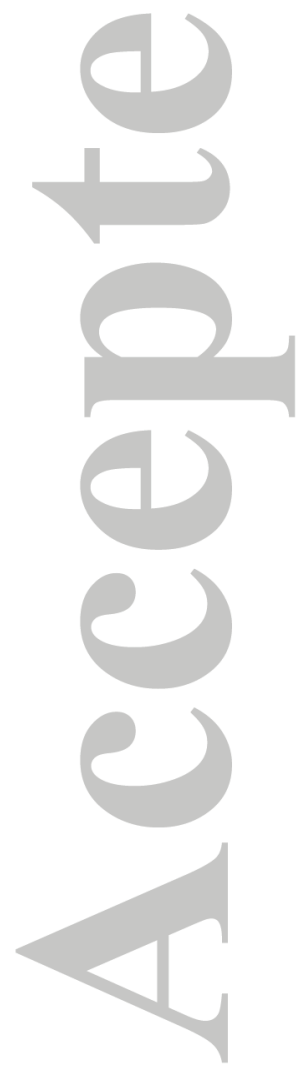




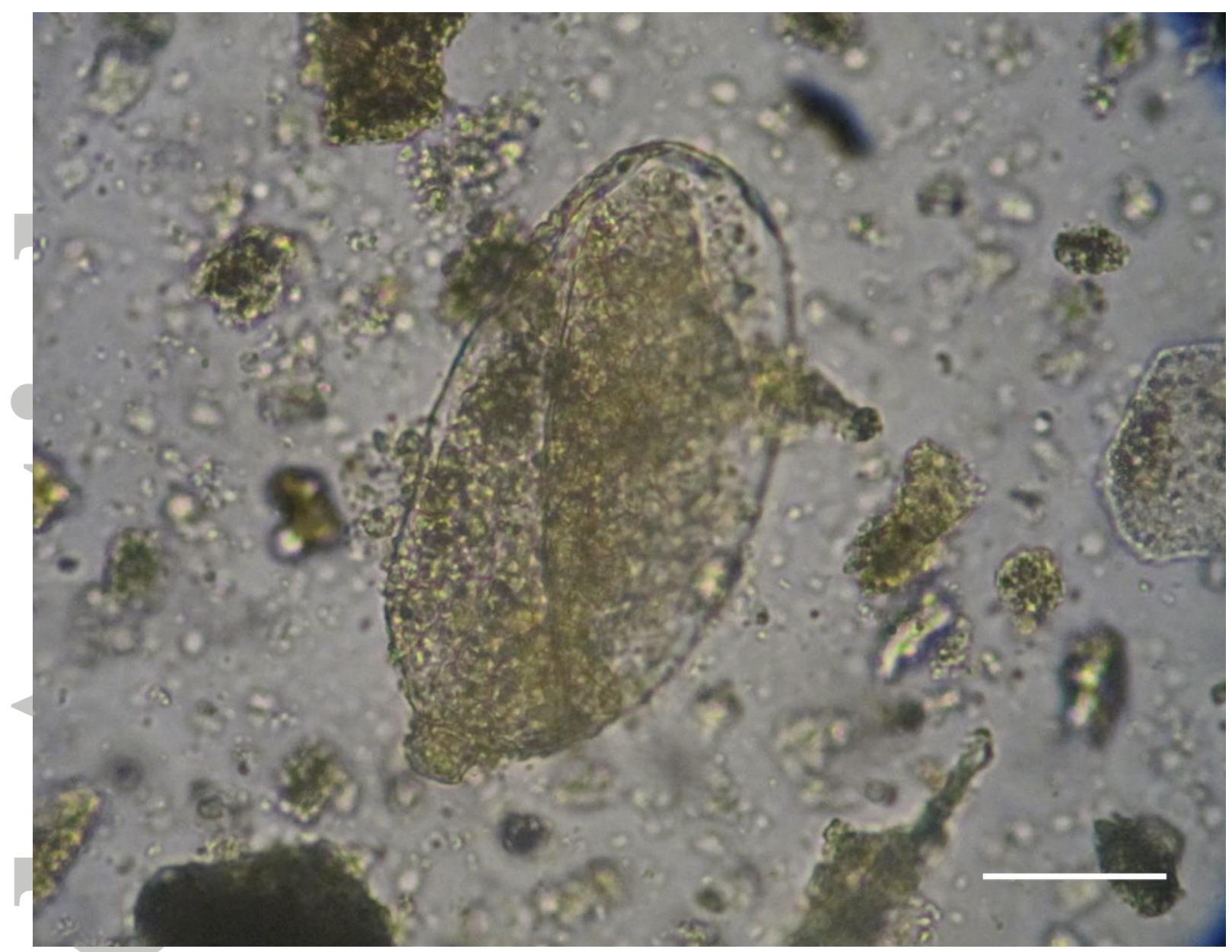

Figure 2a: Helminth egg found in Cueva Galpón, Patagonia, Argentina, compatible to Nematodirus sp. (Strongylida, Trichostrongyloidea). Bar $=40 \mu \mathrm{m}$.

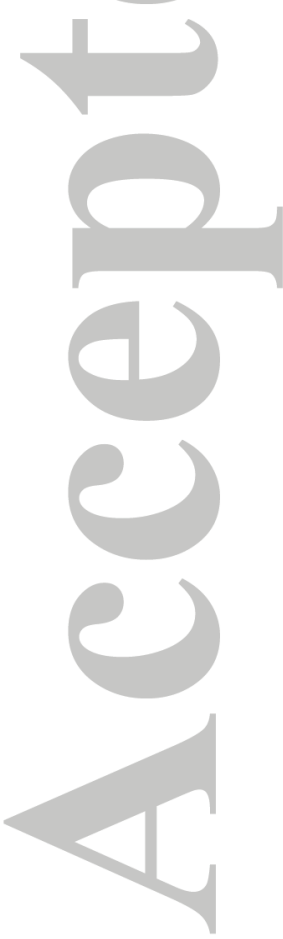

This article is protected by copyright. All rights reserved. 


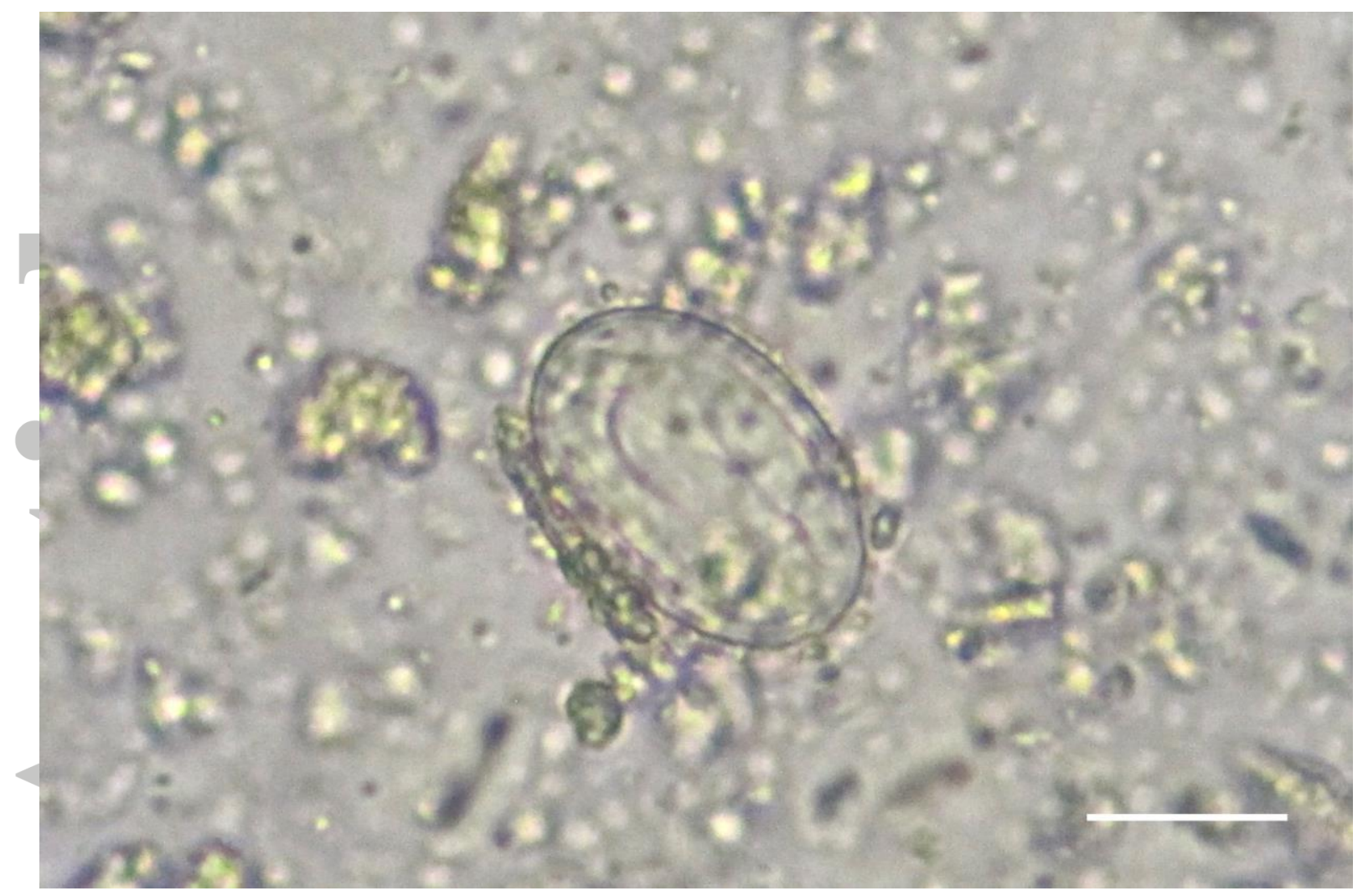

Figure 2b: Helminth egg found in Cueva Galpón, Patagonia, Argentina, assigned to the superfamily Spiruroidea (Order Spirurida). Bar $=20 \mu \mathrm{m}$.

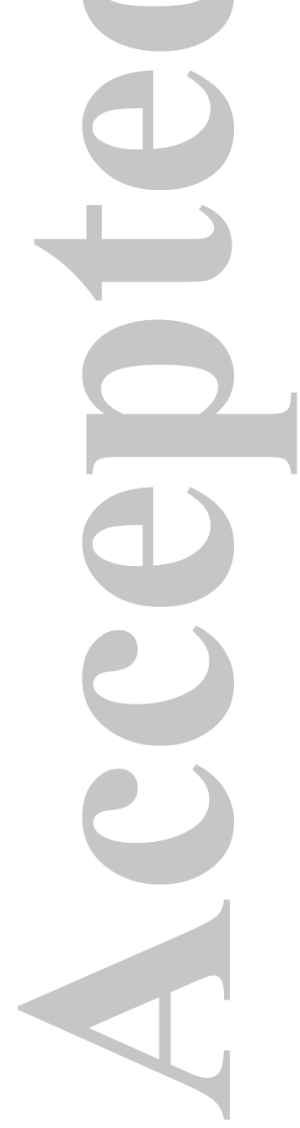

This article is protected by copyright. All rights reserved. 


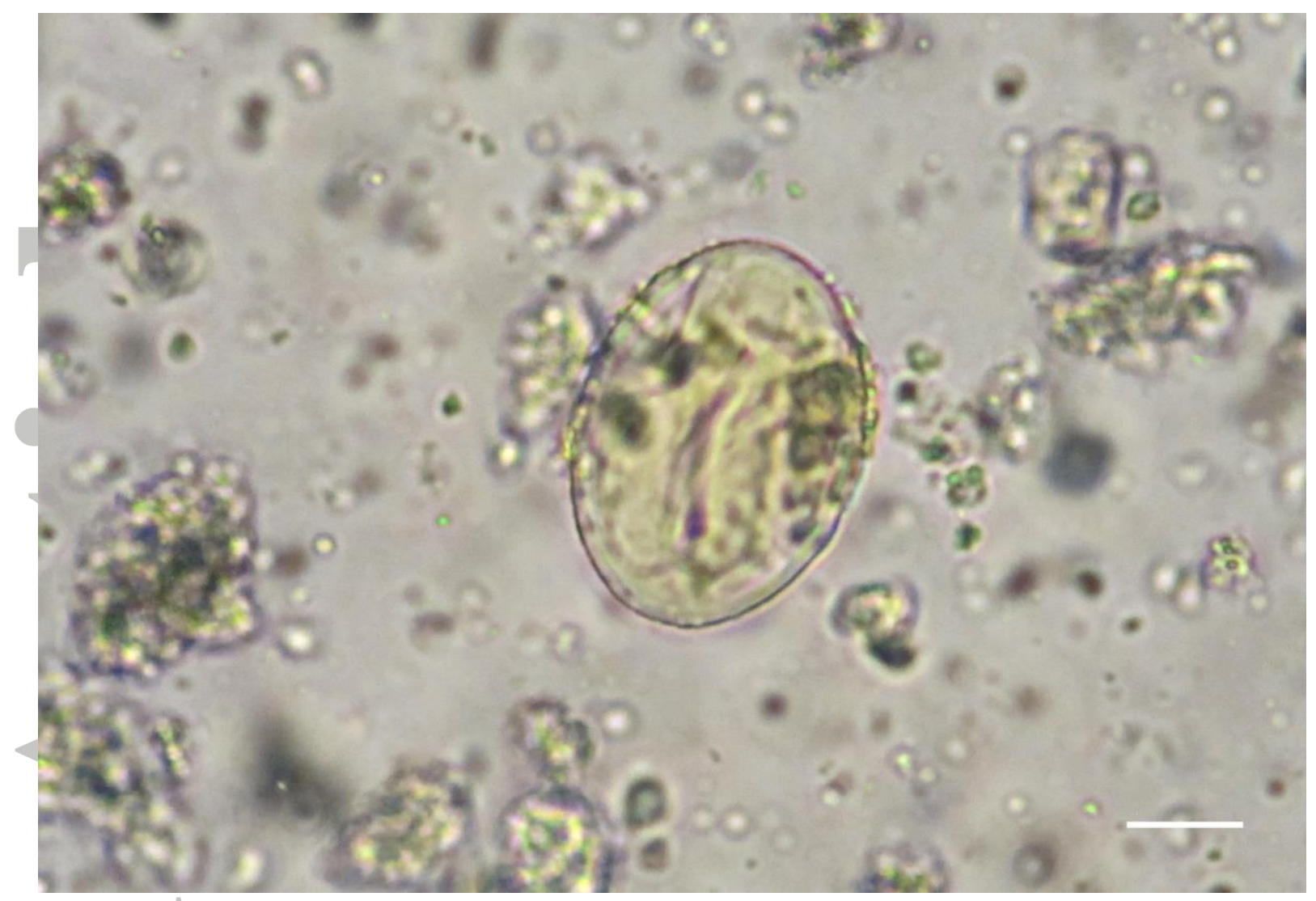

Figure 2c: Helminth egg found in Cueva Galpón, Patagonia, Argentina, attributed to an ascaridid species (Ascaridida, Ascarididae). Bar $=20 \mu \mathrm{m}$.

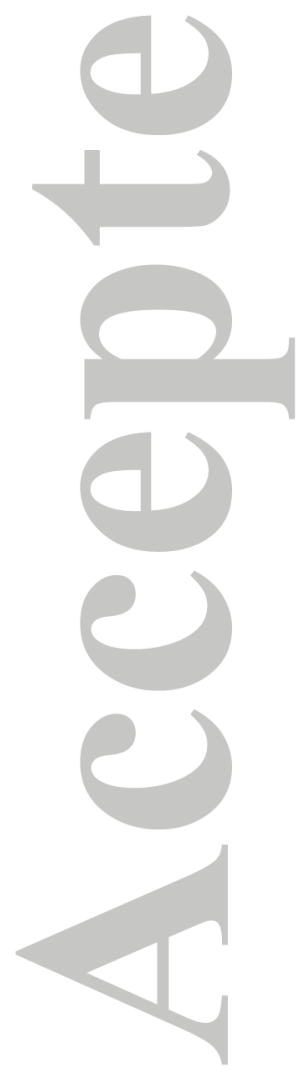

This article is protected by copyright. All rights reserved. 


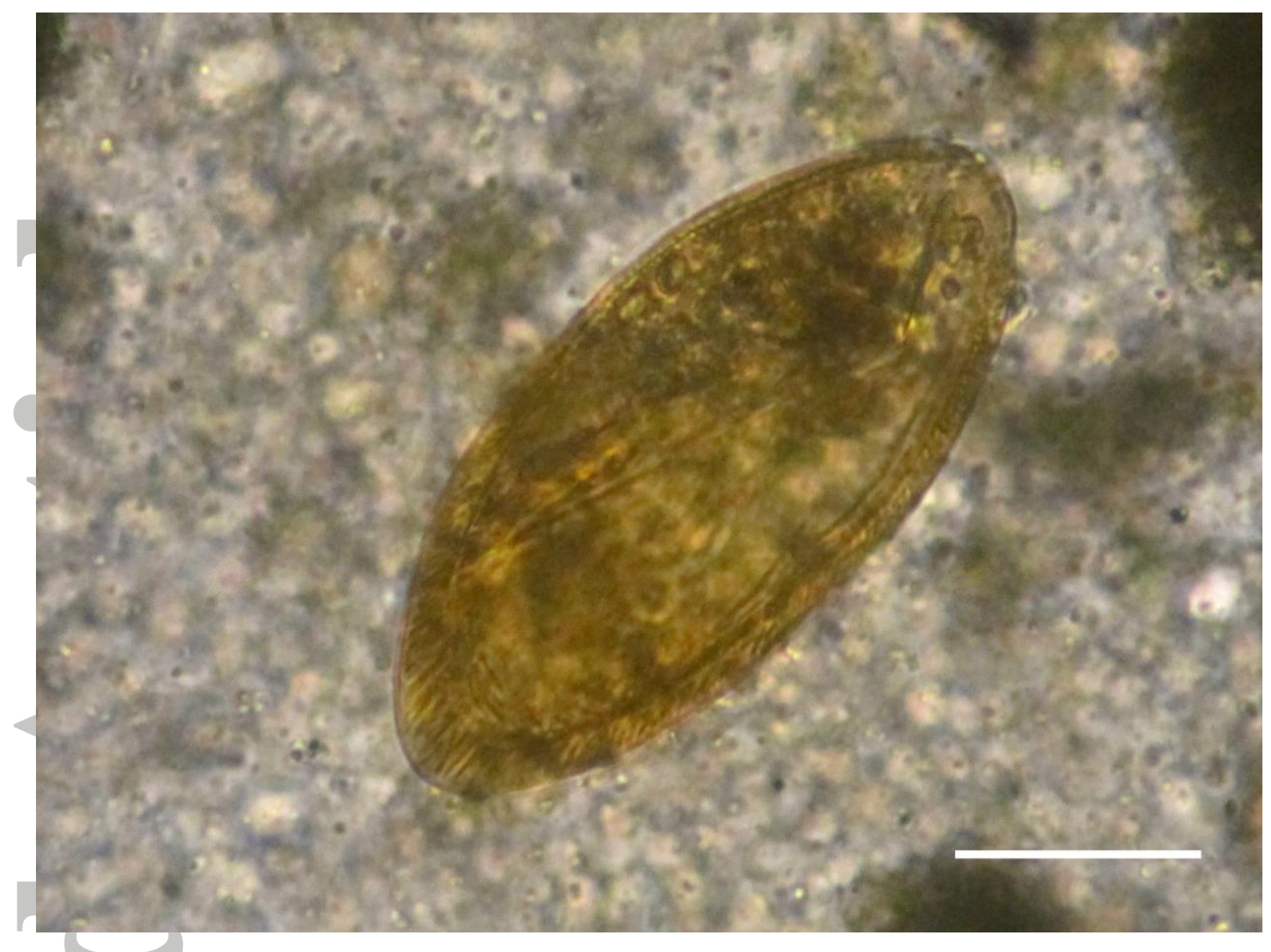

Figure 2d: Helminth egg found in Cueva Galpón, Patagonia, Argentina, assigned to Heteroxynema (Cavioxyura) viscaciae (Oxyuroidea, Heteroxynematidae). Bar $=40 \mu \mathrm{m}$.

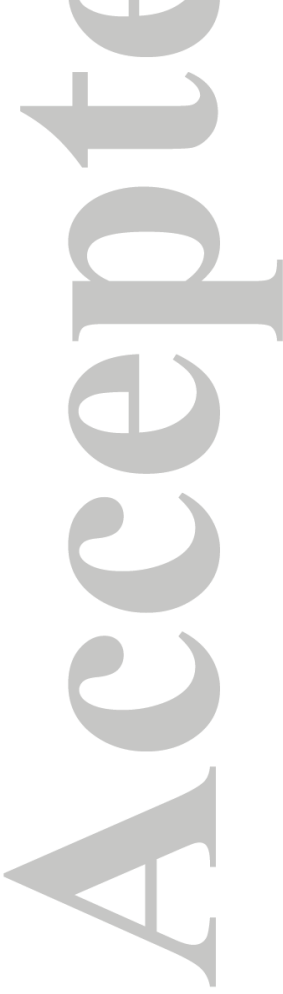

This article is protected by copyright. All rights reserved. 


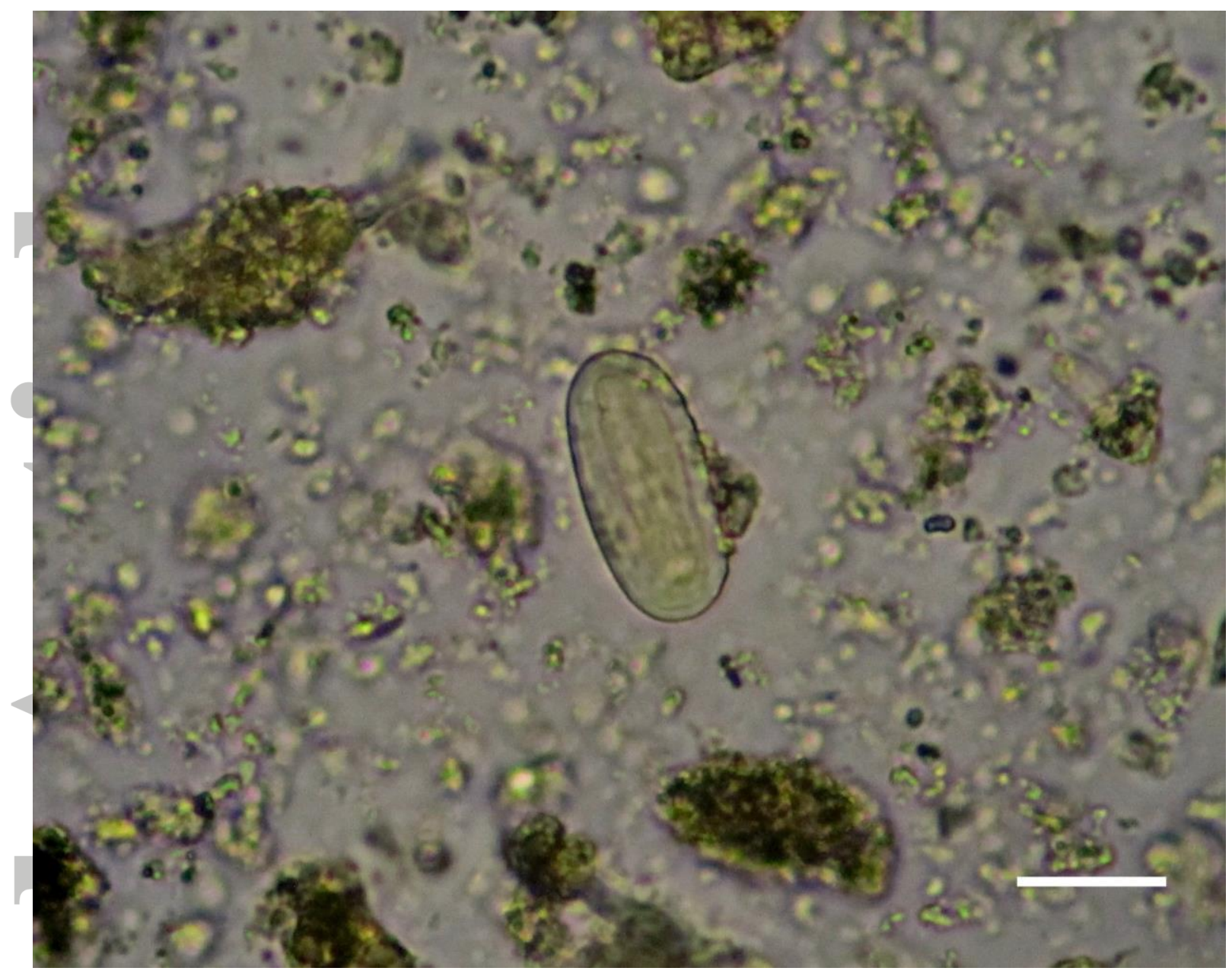

Figure 2e: Helminth egg found in Cueva Galpón, Patagonia, Argentina, attributed to Spirocerca sp. (Spirurida, Spirocercidae). Bar $=20 \mu \mathrm{m}$.

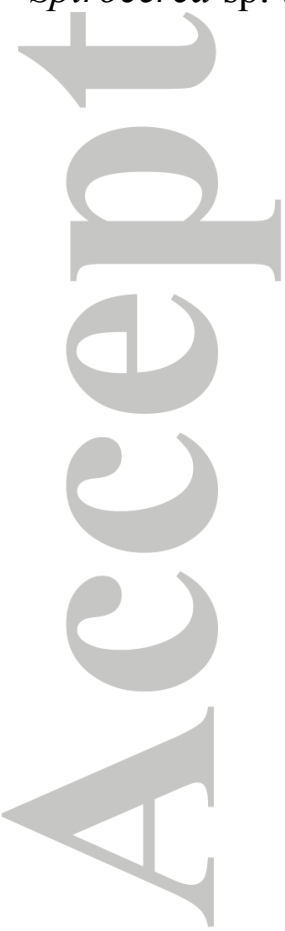




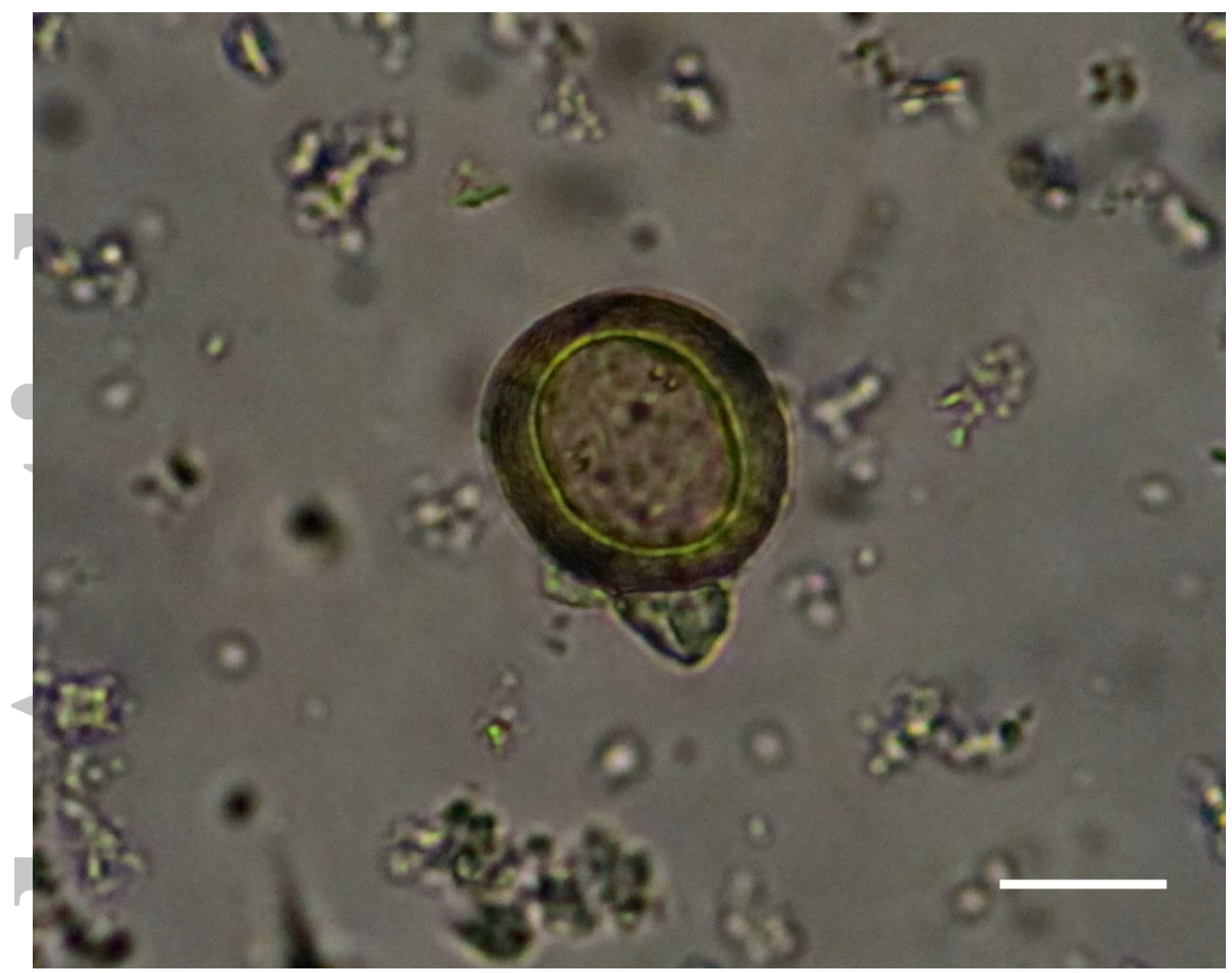

Figure 2f: Helminth egg found in Cueva Galpón, Patagonia, Argentina, identified as Taenia sp. or Echinococcus sp. (Cyclophyllidea, Taeniidae). Bar $=20 \mu \mathrm{m}$.

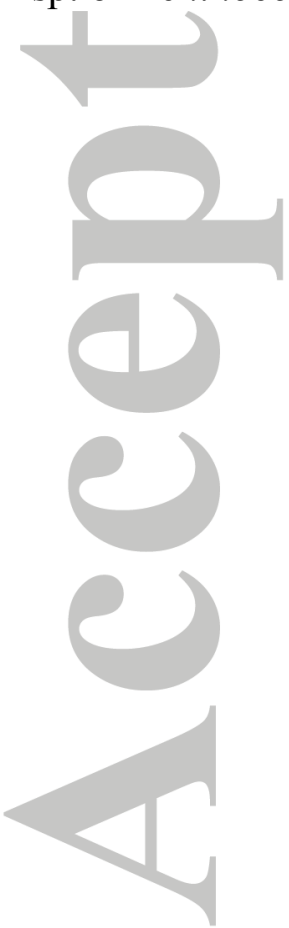

This article is protected by copyright. All rights reserved. 


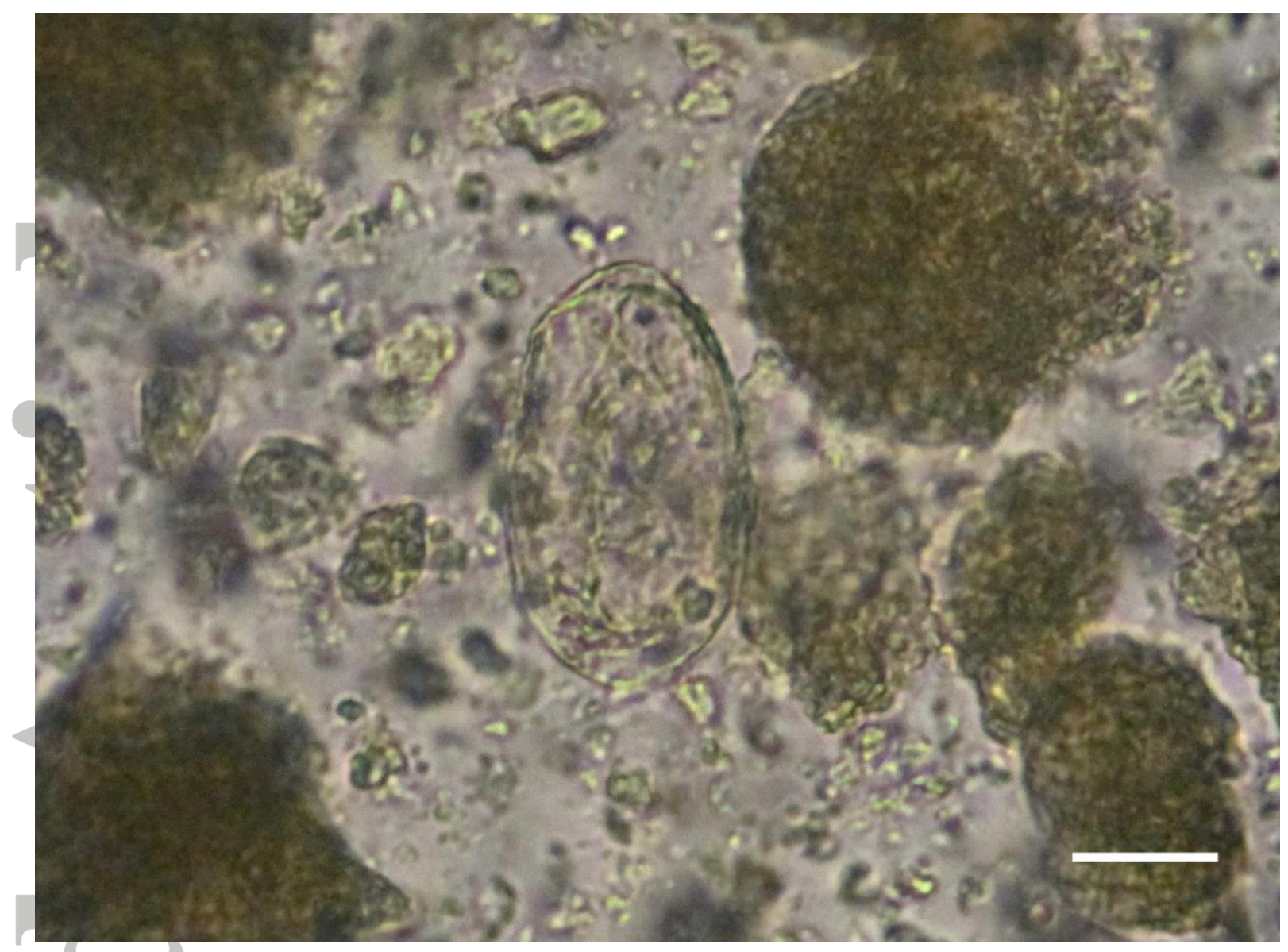

Figure 2g: Helminth egg found in Cueva Galpón, Patagonia, Argentina, attributed to Gnathostoma sp. (Spirurida: Gnathostomatidae). Bar $=20 \mu \mathrm{m}$.



This article is protected by copyright. All rights reserved. 


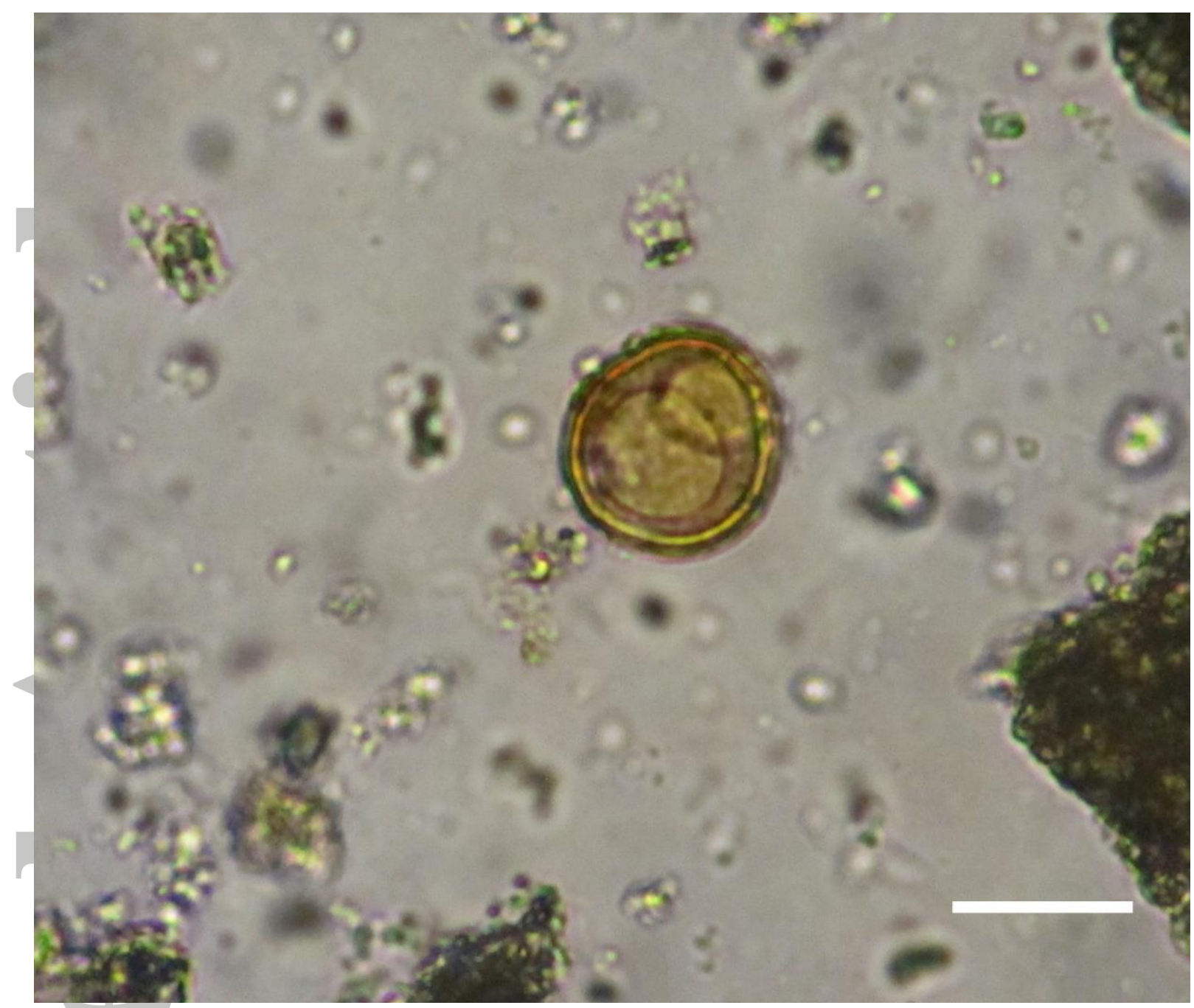

Figure 2h: Oocyst (Coccidia, Apicomplexa) found in Cueva Galpón, Patagonia, Argentina. $\mathrm{Bar}=20 \mu \mathrm{m}$

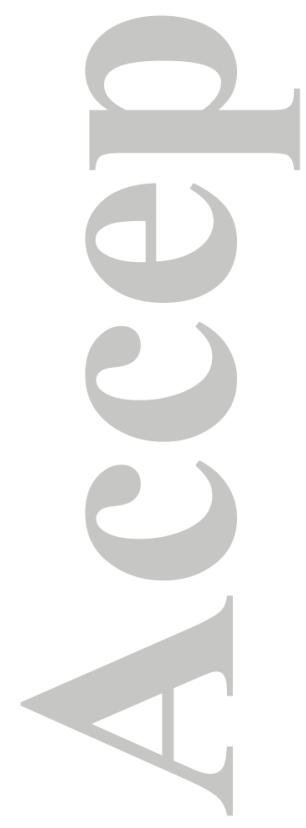

This article is protected by copyright. All rights reserved. 